Article

\title{
Ageing Effects on Room-Temperature Tensile Properties and Fracture Behavior of Quenched and Tempered T92/TP316H Dissimilar Welded Joints with Ni-Based Weld Metal
}

\author{
Lucia Čiripová, Ladislav Falat *, Peter Ševc, Marek Vojtko and Miroslav Džupon \\ Institute of Materials Research, Slovak Academy of Sciences, Watsonova 47, 04001 Košice, Slovakia; \\ lciripova@saske.sk (L.Č.); psevc@saske.sk (P.Š.); mvojtko@saske.sk (M.V.); mdzupon@saske.sk (M.D.) \\ * Correspondence: lfalat@saske.sk; Tel.: +421-55-792-2447
}

Received: 13 September 2018; Accepted: 1 October 2018; Published: 3 October 2018

check for updates

\begin{abstract}
The present work is focused on the investigation of isothermal ageing effects on room-temperature tensile properties and the failure of quenched and tempered martensitic/austenitic weldments between T92 and TP316H heat-resistant steels. The dissimilar weldments were produced by gas tungsten arc welding technique using a Ni-based Thermanit Nicro 82 filler metal. The welded joints were subjected to unconventional post-welding heat treatment consisting of the welds solutionizing $\left(1060{ }^{\circ} \mathrm{C} / 30 \mathrm{~min}\right)$, followed by their water quenching and final stabilization tempering $\left(760^{\circ} \mathrm{C} / 60 \mathrm{~min}\right.$ ). The treatment was completed by spontaneous air cooling within a tempering furnace. The welds in their initial quenched and tempered condition were subsequently aged at $620^{\circ} \mathrm{C}$ for up to $2500 \mathrm{~h}$. Apart from room-temperature tensile tests performed for all the welds material states, additional cross-weld hardness measurements were carried out on longitudinal sections of broken tensile specimens. The applied thermal exposure resulted in recognizable deterioration of plastic properties, whereas their effects on strength properties were rather small. The welds tensile straining and fracture evolution exhibited competitive behavior between the austenitic TP316H region and Ni-based weld metal. The observed failure locations showed significant hardness peaks due to intensive, necking-related strain hardening effects occurred during the tensile tests.
\end{abstract}

Keywords: dissimilar weld; ageing; tensile properties; hardness; failure mode

\section{Introduction}

Dissimilar welded joints between tempered martensitic and austenitic heat-resistant steels are typically used in high temperature steam circuits of ultra-supercritical (USC) power-plant boilers; e.g., for inter-linking header equipment with superheater tubes. Previous findings of several published studies (e.g., [1-4]) indicated the use of Ni-based weld metal (Ni WM) to be suitable means to suppress undesirable carbon diffusion across dissimilar metal weld interfaces and thus to retard local creation of carbon-depleted and carbon-enriched microstructural regions. It has been generally accepted that fusion welded joints of martensitic creep-resistant steels require the application of post-welding heat treatment (PWHT) in order to reduce thermally-induced and transformation-induced residual welding stresses and also to produce thermally more stable tempered martensitic microstructures with sufficient toughness [5-9]. In contrast, the welded joints of austenitic heat-resistant steels do not generally require any specific PWHT. In the case of Ni-based transition weldments between tempered martensitic and austenitic heat-resistant steels, an application of PWHT is necessary to be performed according to specifications applicable for martensitic steels welded joints [10-12]. Classical conception for PWHT processing of martensitic/austenitic weldments is based on their subcritical tempering; 
i.e., the tempering below Ac1 critical transformation temperature of ferrite-to-austenite phase transformation of tempered martensitic steel base material. Conventionally established procedure for fabrication of Ni-based transition weldments between ferritic (incl. tempered martensitic) and austenitic boiler steels' pipes of greater diameters consists of an initial deposition of Ni-base alloy buttering layer onto a prepared welding edge of ferritic steel pipe [13-16]. The segment of ferritic steel base material with prepared Ni-based buttering layer is commonly subjected to conventional PWHT; i.e., subcritical tempering below the steel Ac1 critical transformation temperature. After performing this PWHT, final multi-pass welding of Ni-buttered ferritic steel segment with its austenitic steel counter-part is performed using Ni-based electrode to complete the dissimilar welded joint without the need for any further heat treatment [13-16]. However, in the case of dissimilar welds between ferritic and austenitic boiler tubes with smaller diameters, direct welding with $\mathrm{Ni}$-based electrode is performed without Ni-alloy pre-buttering and then the whole weldment is subjected to PWHT [10,11,17-20].

Our previous works [18-20] were focused on the comparison between the effects of conventional "tempering PWHT" ("T PWHT") and unconventional "quenching-and-tempering PWHT" ("QT PWHT") of T92/TP316H martensitic/austenitic weldments on their high-temperature creep resistance, room-temperature hardness, impact toughness, and notch-tensile properties of thermally exposed T92 steel heat-affected zone (T92 HAZ) in relation to its long-term microstructure evolution. It has been found out that after the "QT PWHT" the microstructures and properties of all materials regions within the whole T92/TP316H weldment became homogenized in comparison to those of the weldment after the "T PWHT". The initial microstructural heterogeneity of T92 HAZ region was completely suppressed after the "QT PWHT" thanks to the weld full re-austenitization. Thus, the creep resistance of the weldments after the "QT PWHT" notably increased as a result of premature "type IV creep failure" elimination $[18,19]$.

In contrast to our previous works on T92/TP316H martensitic/austenitic weldments with Nirod 600 Ni WM [18-20], the present study representing our continuous research work deals with isothermal ageing effects on room-temperature tensile properties and failure behavior of notch-free, quenched, and tempered T92/TP316H martensitic/austenitic weldments with Thermanit Nicro $82 \mathrm{Ni}$ WM. The characterization of the overall tensile deformation and fracture behavior of the weldments without artificial stress concentrators in dependence of applied ageing exposure is presented. The correlation between thermally induced microstructural changes and mechanism of mechanical properties degradation is discussed.

\section{Materials and Methods}

The experimental Ni-based transition weldments between the tubes (outer diameter $38 \mathrm{~mm}$, wall thickness $5.6 \mathrm{~mm}$ ) of T92 tempered martensitic and TP316H austenitic heat-resistant steels were prepared in the company SES a. s. Tlmače, Slovakia by gas tungsten arc welding (GTAW) using "Inconel-type" filler metal Thermanit Nicro 82. The preparation of welding edges and sequence of welding passes are schematically shown in Figure 1.

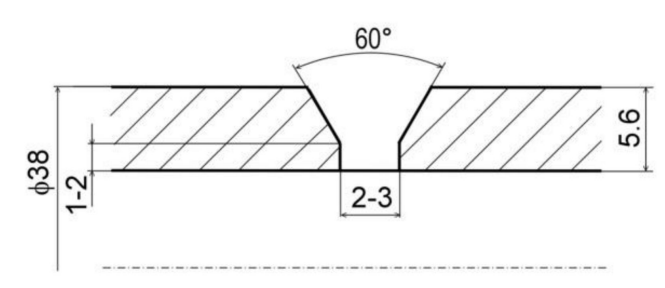

(a)

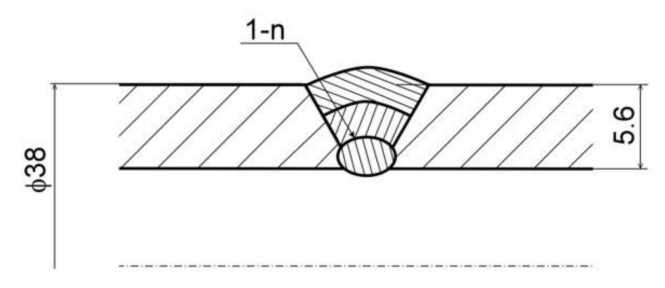

(b)

Figure 1. The preparation of welding edges (a) and sequence of welding passes (b). All dimensions are in $\mathrm{mm}$. The " $\mathrm{n}$ " represents the number of welding passes in range from 2 to 3. 
The welding conditions included welding current in the range from 70 to $110 \mathrm{~A}$, voltage from 12 to $17 \mathrm{~V}$, and heat input from 9 to $12 \mathrm{~kJ} / \mathrm{cm}$. The electrode diameter was $2.4 \mathrm{~mm}$. The chemical composition of dissimilar base materials and Ni-based filler metal used for fabrication of the investigated dissimilar weldments is shown in Table 1.

Table 1. Chemical composition (wt.\%) of individual materials used for fabrication of T92/TP316H dissimilar weldments with Ni-based weld metal.

\begin{tabular}{cccccccccccccc}
\hline Material & $\mathbf{C}$ & $\mathbf{N}$ & $\mathbf{S i}$ & $\mathbf{M n}$ & $\mathbf{C r}$ & $\mathbf{M o}$ & $\mathbf{W}$ & $\mathbf{B}$ & $\mathbf{N i}$ & $\mathbf{T i}$ & $\mathbf{V}$ & $\mathbf{N b}$ & $\mathbf{F e}$ \\
\hline T92 & 0.11 & 0.05 & 0.38 & 0.49 & 9.08 & 0.31 & 1.57 & 0.002 & 0.33 & - & 0.2 & 0.07 & rest \\
TP316H & 0.05 & - & 0.51 & 1.77 & 16.76 & 2.05 & - & - & 11.13 & - & - & - & rest \\
Ni WM $^{\#}$ & 0.01 & - & 0.07 & 3.21 & 20.71 & 0.004 & - & - & rest & 0.37 & & 2.6 & 0.31 \\
\hline
\end{tabular}

The produced tubular segments of T92/TP316H weldments were subjected to unconventional QT PWHT including the welds full re-austenitization at $1060{ }^{\circ} \mathrm{C}$ for $30 \mathrm{~min}$, their water quenching and subsequent subcritical tempering at $760{ }^{\circ} \mathrm{C}$ for 1 hour, completed by passive air cooling within electric resistance furnace LAC PKE 18/12R (LAC, s.r.o., Rajhrad, Czech Republic). The heating rate for obtaining individual stages of QT PWHT was maximally $150{ }^{\circ} \mathrm{C} / \mathrm{h}$. All further experimental work was performed using cca. $60 \mathrm{~mm}$ long cross-weld (c-w) samples prepared from the tubular weldments using spark erosion machine EIR-EMO 2N (Emotek s.r.o., Nove Mesto nad Vahom, Slovak Republic). Schematic c-w sampling is shown in Figure 2.

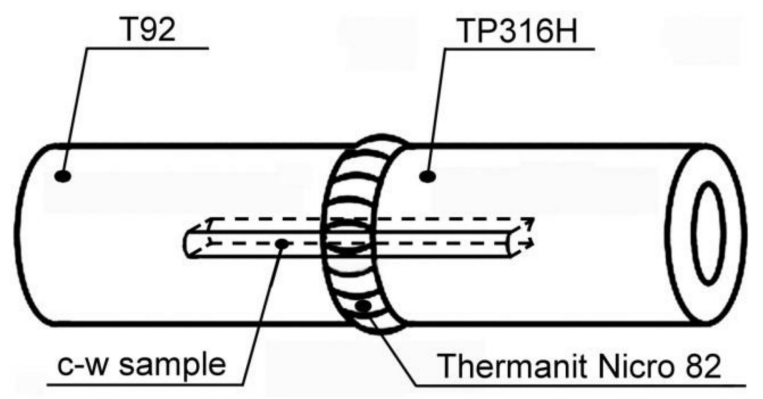

Figure 2. Schematic cross-weld (c-w) sampling.

One series of $\mathrm{c}-\mathrm{w}$ samples was investigated in its initial QT PWHT state which was considered as the reference state. The second series and the third series of $\mathrm{c}-\mathrm{w}$ samples were isothermally exposed at $620{ }^{\circ} \mathrm{C}$ for 500 and $2500 \mathrm{~h}$, respectively. All the three material states (QT PWHT, QT PWHT + $620{ }^{\circ} \mathrm{C} / 500 \mathrm{~h}, \mathrm{QT}$ PWHT $+620{ }^{\circ} \mathrm{C} / 2500 \mathrm{~h}$ ) were subjected to room-temperature c-w tensile testing. Uniaxial room-temperature tensile tests of conventionally machined M6 threaded cylindrical tensile specimens (see Figure 3) were carried out by employing TIRATEST 2300 universal testing machine (TIRA GmbH, Schalkau, Germany) at a cross-head speed of $0.05 \mathrm{~mm} / \mathrm{min}$. Three individual c-w tensile test specimens were tested for each material state of the studied weldments. From recorded engineering stress-strain curves the average values of yield stress (YS) and ultimate tensile strength (UTS) were determined. The individual values of YS were graphically estimated as $0.2 \%$ proof stress. The average values of total elongation at fracture (EL) and reduction of area at fracture (RA) were obtained from micrometrical measurements performed directly on the broken tensile specimens. The evaluation of $\mathrm{c}-\mathrm{w}$ tensile properties included the calculation of their standard deviations.

In order to indicate local strain hardening effects in investigated dissimilar weldments during the tensile tests, $c-w$ Vickers hardness measurements were performed on plain surfaces of prepared longitudinal sections of broken tensile specimens after the tensile tests. The hardness measurements were performed using a Vickers 432 SVD hardness tester (Wolpert Wilson Instruments, division of INSTRON DEUTSCHLAND GmbH, Aachen, Germany) with $98 \mathrm{~N}$ loading for 10 s per measurement. 
The reference material state was represented by the original unstrained c-w specimen (i.e., the specimen that was not subjected to tensile testing) in its initial QT PWHT condition.

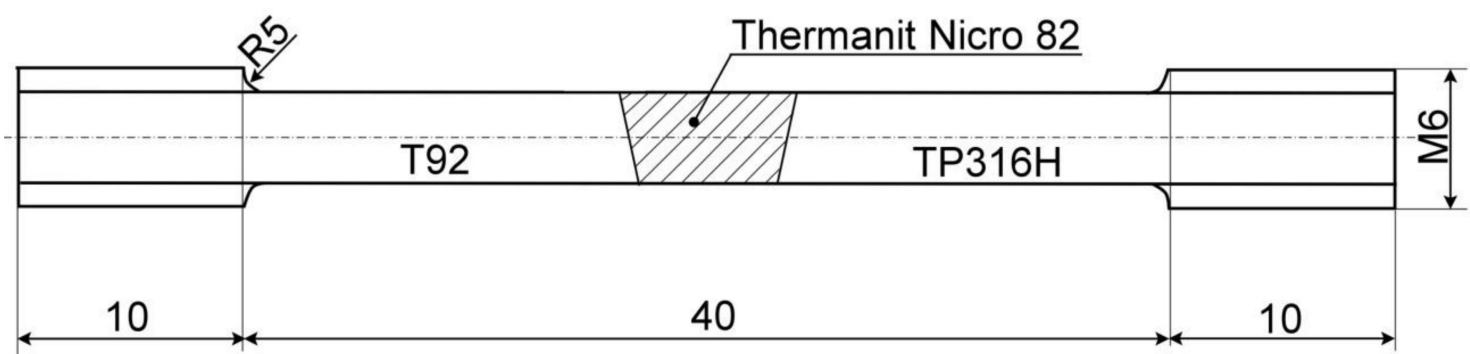

Figure 3. The tensile test specimen for cross-weld tensile testing of dissimilar weldments. All dimensions are in $\mathrm{mm}$.

Microstructure, fracture path, and fracture surface analyses of the selected representative samples corresponding to individual material states were performed using light optical microscope OLYMPUS GX71 (OLYMPUS Europa Holding GmbH, Hamburg, Germany), scanning electron microscope JEOL JSM-7000F (Jeol Ltd., Tokyo, Japan) with an energy-dispersive X-ray spectroscopy (EDX) analyzer INCA X-sight model 7557 (Oxford Instruments, Abingdon, Oxfordshire, UK), and environmental scanning electron microscope EVO MA15 (Carl Zeiss Microscopy GmbH, Jena, Germany), respectively.

\section{Results and Discussion}

\subsection{Microstructure in Initial QT PWHT State}

Figure 4 shows general view on microstructural profile comprising of individual material regions of dissimilar T92/TP316H weldment with Thermanit Nicro 82 Ni-based weld metal (Ni WM) in its initial QT PWHT condition. In accordance with our previous studies about the effects of various PWHT regimes on a very similar type of dissimilar T92/TP316H weldments with Nirod $600 \mathrm{Ni}$ WM [18-20], the microstructures of all material regions of the presently investigated weldment are clearly coarse-grained and homogenized without the presence of traditionally heterogeneous T92 HAZ microstructural gradient, as a result of performed re-austenitization; i.e., the solutionizing stage of performed two-step QT PWHT.

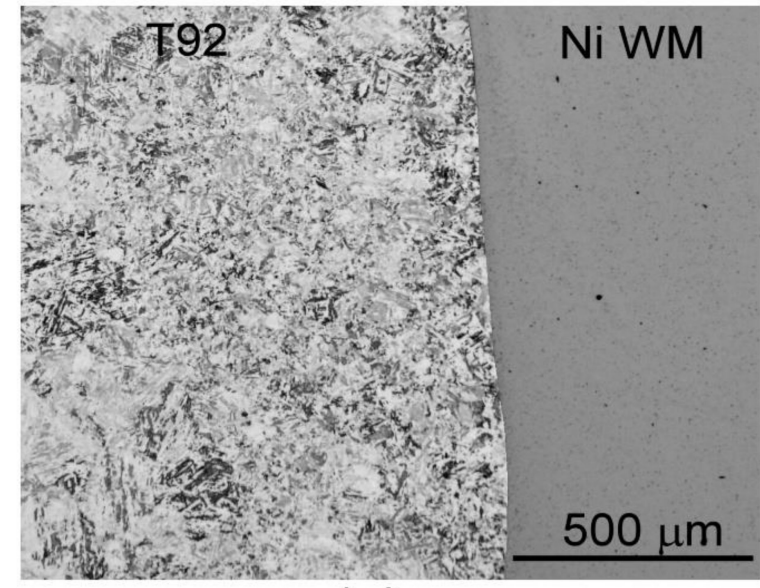

(a)

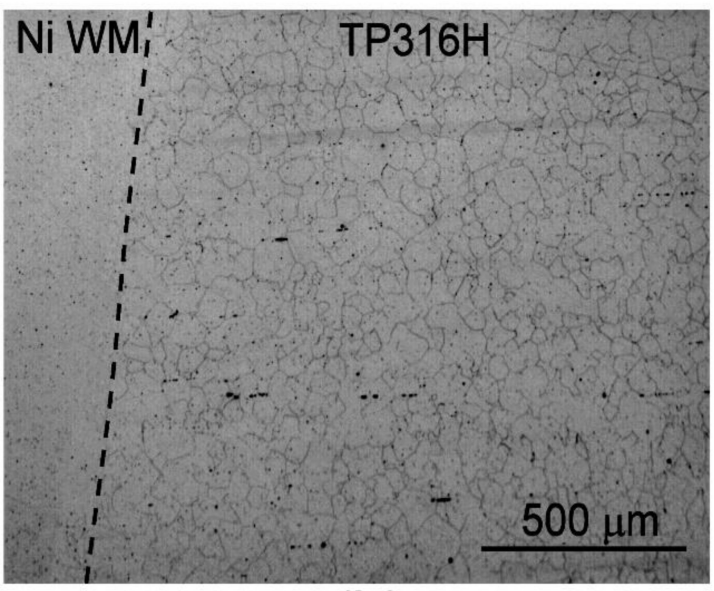

(b)

Figure 4. The general view on individual microstructural regions of T92/TP316H dissimilar weldment with Ni-based weld metal: T92/Ni WM region (a); Ni WM/TP316H region (b). 
This means that the T92 steel region next to the Ni WM (Figure 4a) does not consist of several microstructural sub-regions such as coarse-grained HAZ (CGHAZ), fine-grained HAZ (FGHAZ), intercritical HAZ (ICHAZ), and subcritical HAZ (SCHAZ), which are commonly present within the HAZ regions of ferritic steels' welded joints subjected to conventional single-step "T PWHT" [17-22]. Figure $4 \mathrm{~b}$ shows the general view on QT microstructures of NiWM and TP316H austenitic regions exhibiting polygonal grains with secondary phase precipitates. Figure 5 shows the detailed microstructure of the T92 region of the investigated weldment formed of homogenized and tempered martensite, typically consisting of tempered martensitic laths inside the blocks and packets structures within prior austenitic grains. In accordance with numerous research studies focused on normalized and tempered grade 92 steels (e.g., [6-11,23-25]), the phase composition of the T92 steel region of the investigated weldment in its initial QT PWHT condition consists of ferrite matrix and secondary phase precipitates, namely intergranular $\mathrm{M}_{23} \mathrm{C}_{6}(\mathrm{M}=\mathrm{Cr}, \mathrm{Fe}, \ldots)$ carbides and intragranular $\mathrm{MX}(\mathrm{M}=\mathrm{V}, \mathrm{Nb}$; $\mathrm{X}=\mathrm{C}, \mathrm{N}$ ) carbo-nitrides.
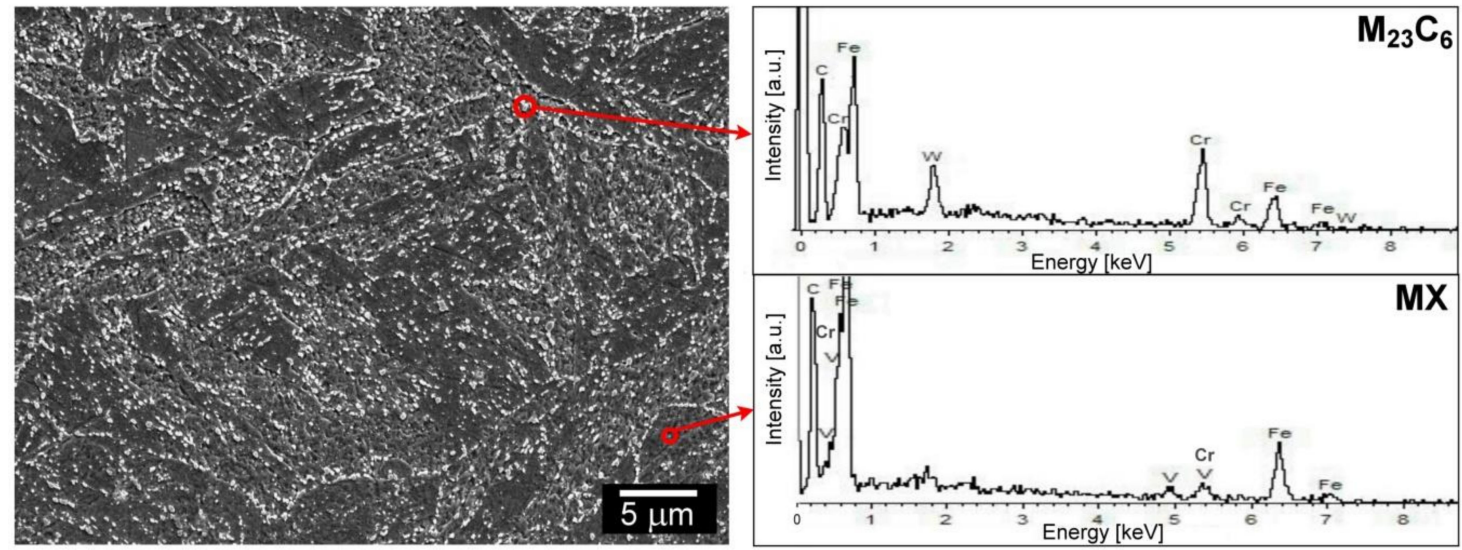

Figure 5. Scanning electron microscope (SEM)-micrograph of T92 steel region of the investigated T92/TP316H dissimilar weldment in "QT PWHT" condition and typical energy-dispersive X-ray spectroscopy (EDX)-spectra from spot-EDX analyses of $\mathrm{M}_{23} \mathrm{C}_{6}$ and $\mathrm{MX}$ secondary phase particles.

Figure 6 shows the initial QT PWHT microstructure of Thermanit Nicro $82 \mathrm{Ni}$ WM, which consists of so-called "nickel-austenite" matrix with randomly distributed, blocky primary precipitates, namely $(\mathrm{Ti}, \mathrm{Nb})(\mathrm{C}, \mathrm{N})$ or $(\mathrm{Ti}, \mathrm{Nb}, \mathrm{B})(\mathrm{C}, \mathrm{N})$ carbo-nitrides, $(\mathrm{Nb}, \mathrm{B}) \mathrm{C}$ carbides and secondary precipitates of $\mathrm{Cr}_{23} \mathrm{C}_{6}$ carbides and $\mathrm{NbC}$ carbides located on grain boundaries as well as in grain interiors.
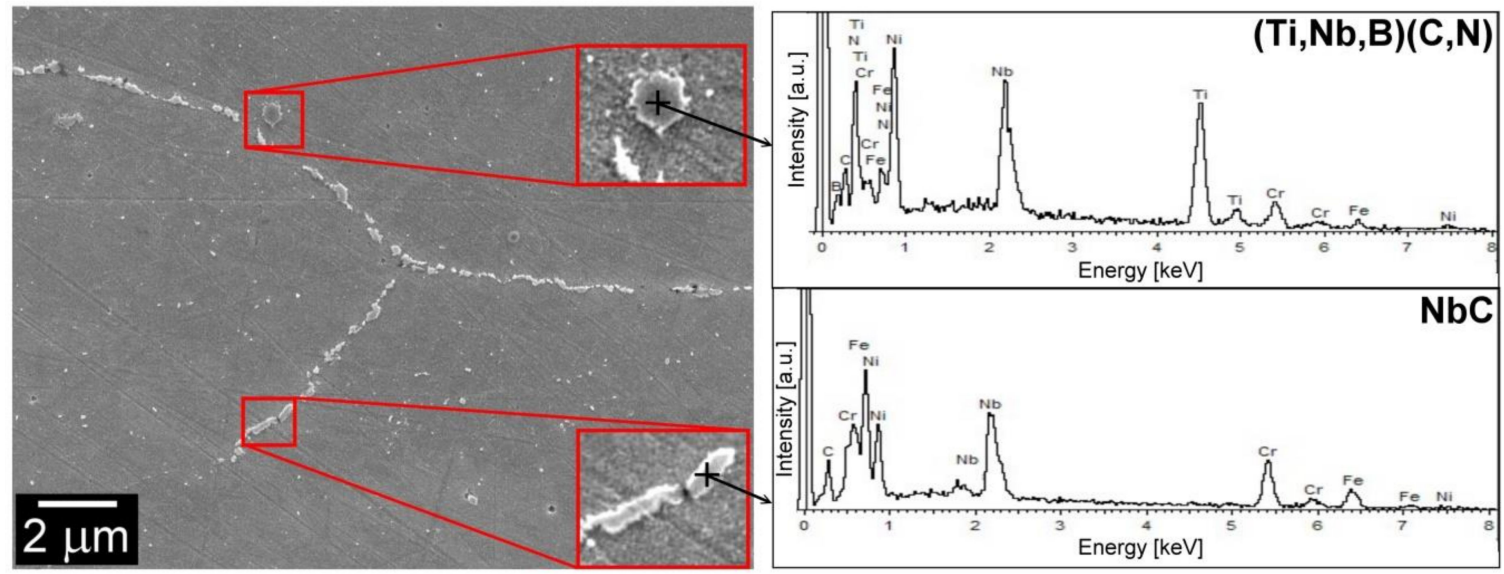

Figure 6. SEM-micrograph of Ni-based weld metal (Ni WM) region Thermanit Nicro 82 of the investigated T92/TP316H dissimilar weldment in "QT PWHT" condition and typical EDX-spectra from spot-EDX analyses of primary $(\mathrm{Ti}, \mathrm{Nb}, \mathrm{B})(\mathrm{C}, \mathrm{N})$ and secondary $\mathrm{NbC}$ precipitate particles. 
Since Thermanit Nicro 82 filler metal does not contain any boron and nitrogen, the presence of these two elements in the primary precipitates is likely to be a result of Ni WM dilution effect due to its mixing during the welding with T92 base material, which contains both a B and N micro-alloying elements (see Table 1). In agreement with our previous works [18-20], the initial microstructure of the TP316H steel region of the studied weldment in a QT PWHT state is formed of polygonal, fully recrystallized austenitic grains with only very fine discontinuous films of $\mathrm{M}_{23} \mathrm{C}_{6}$ carbide precipitates on grain boundaries (see Figure 7).
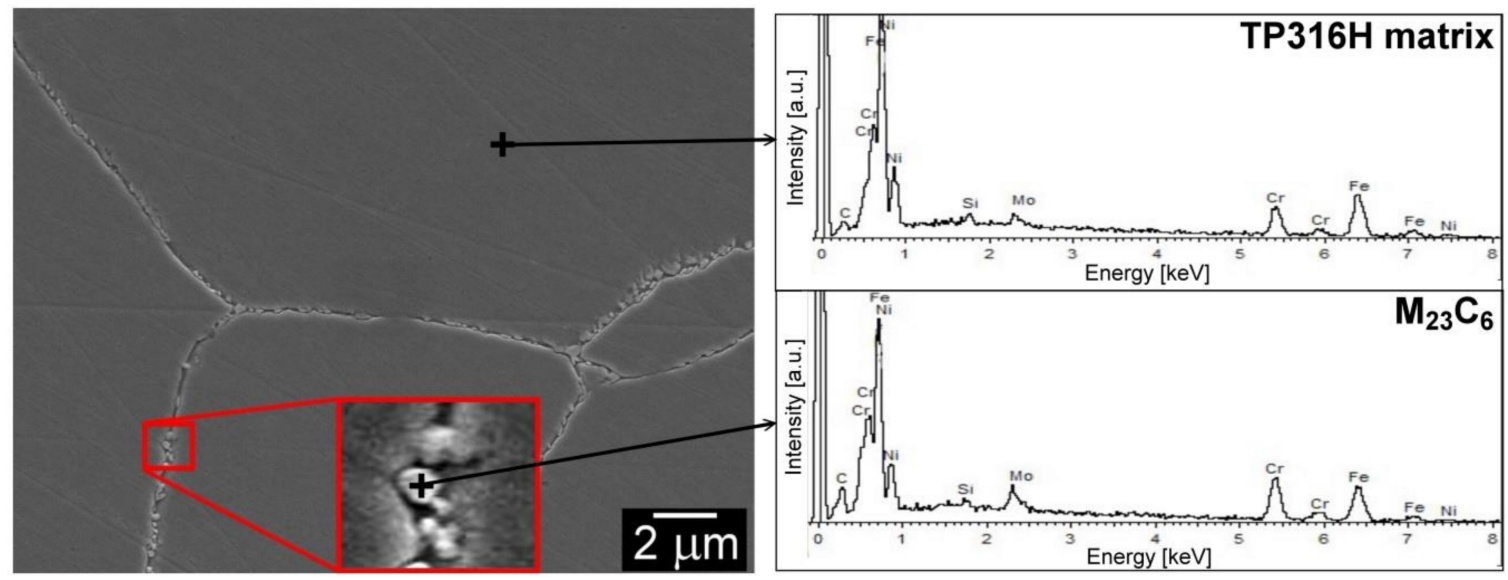

Figure 7. SEM-micrograph of TP316H steel region of the investigated T92/TP316H dissimilar weldment in "QT PWHT" condition and typical EDX-spectra from spot-EDX analyses of the steel matrix and $\mathrm{M}_{23} \mathrm{C}_{6}$ secondary phase precipitates.

This clearly indicates that the TP316H base material (BM) has not been thermally sensitized during performed QT PWHT.

\subsection{Ageing Effects on Room-Temperature Tensile Properties and Hardness}

The effects of isothermal ageing at $620{ }^{\circ} \mathrm{C}$ up to $2500 \mathrm{~h}$ of the studied weldments on their room-temperature tensile properties are shown in Figure 8.

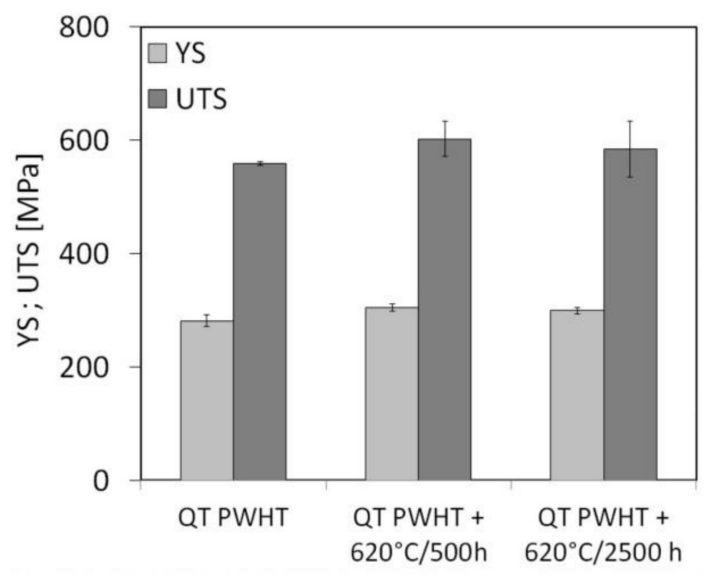

(a)

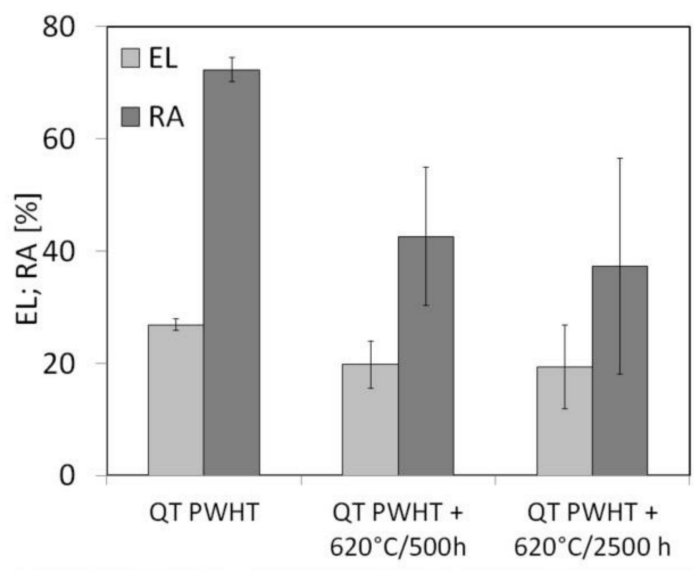

(b)

Figure 8. Ageing effects at $620^{\circ} \mathrm{C}$ on room-temperature tensile properties of T92/TP316H dissimilar weldments with Ni-based weld metal.

It can be seen that applied thermal exposure of the weldments resulted only in negligible effects on their yield stress (YS) and ultimate tensile strength (UTS). In contrast, the welds ageing effects were manifested by recognizable decrease of the both measured plastic properties, namely reduction 
of area at fracture (RA) and total elongation (EL), whereby the RA values showed more significant deterioration at greater value scattering. Similar behavior has also been observed in our former studies [20,26-28] about ageing effects on microstructure and properties of several different types of boiler steels and their weldments. For the sake of comparison, Figure 9 shows three selected engineering stress-strain curves representing characteristics of tensile deformation behavior related to individual material states of the welds under investigation.

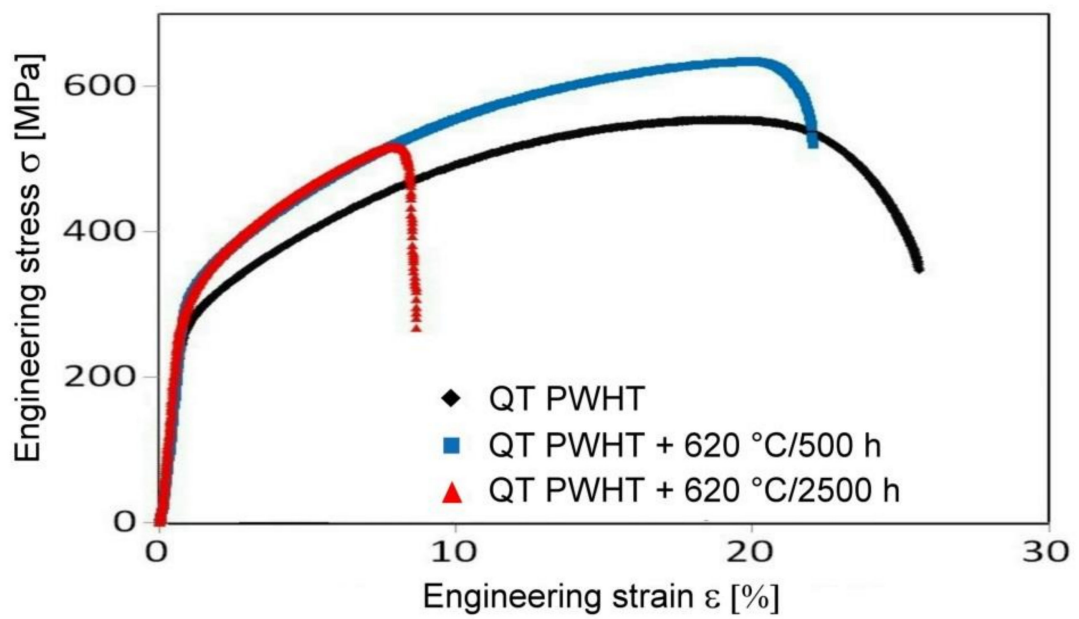

Figure 9. Ageing effects at $620^{\circ} \mathrm{C}$ on tensile deformation behavior of T92/TP316H dissimilar weldments with $\mathrm{Ni}$-based weld metal.

The reason for decreasing plasticity during thermal ageing is generally related to coarsening of secondary phase precipitates. Typical examples of currently observed mechanisms of the plasticity deterioration will be demonstrated and discussed in section 3.3. Figure 10 shows four selected graphs depicting the results of $\mathrm{c}-\mathrm{w}$ hardness profile measurements related to individual material states of the studied weldments.

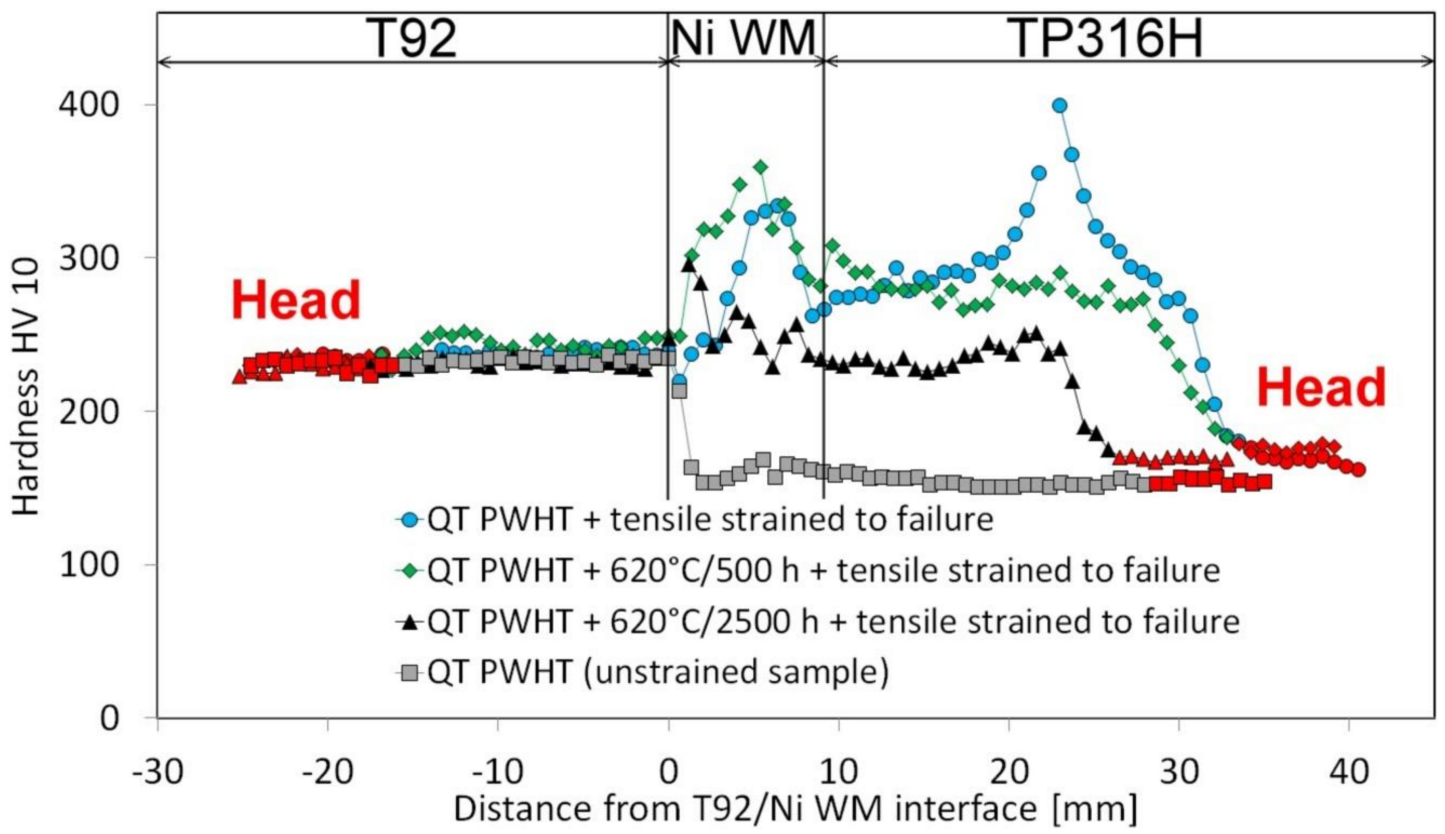

Figure 10. The effects of $620{ }^{\circ} \mathrm{C}$ isothermal ageing and subsequent room-temperature tensile testing on cross-weld hardness profiles of T92/TP316H dissimilar weldments with Ni-based weld metal. 
The original undeformed c-w sample (i.e., the sample that was not subjected to tensile testing) in its initial QT PWHT state clearly shows that the T92 quenched and tempered martensitic part of the studied dissimilar welded joint exhibits the highest hardness values compared to the rest of the austenitic regions (Ni WM and TP316H). In addition, the T92 region does not exhibit a typical steep hardness gradient which is well-known in ferritic steels' weldments subjected to conventional T PWHT regime $[3,13,14,18-20]$. By contrast, it exhibits smooth equalized course of hardness values as a result of homogenization effect of performed QT PWHT. Visible interruptions within the next c-w hardness profiles (Figure 10) indicate the failure locations of broken test specimens after conduction of room-temperature tensile tests. It is worth noting that the austenitic regions (TP316H and Ni WM) of $\mathrm{c}-\mathrm{w}$ samples after all performed tensile tests show notably increased hardness values that are even higher than those of the T92 tempered martensitic weld portions. This observation can be directly related to significantly higher strain hardening effects in the austenitic weld regions than those in the T92 tempered martensitic weld part. Figure 10 also indicates negligible deformability of the tensile samples' head portions. The complete overview of room-temperature tensile properties and all failure locations occurred after the tensile tests are summarized in Table 2.

Table 2. The complete overview of room-temperature tensile properties and failure locations of T92/TP316H dissimilar weldments with Ni-based weld metal for individual material states.

\begin{tabular}{ccccccc}
\hline $\begin{array}{c}\text { Specimen } \\
\text { Number }\end{array}$ & $\begin{array}{c}\text { Material } \\
\text { State }\end{array}$ & $\begin{array}{c}\text { YS } \\
{[\mathbf{M P a}]}\end{array}$ & $\begin{array}{c}\text { UTS } \\
{[\mathbf{M P a}]}\end{array}$ & $\begin{array}{c}\text { EL } \\
{[\%]}\end{array}$ & $\begin{array}{c}\text { RA } \\
{[\%]}\end{array}$ & Failure Location \\
\hline 1 & & 258 & 545 & 25 & 69 & TP316H BM \\
2 & QT PWHT & 265 & 562 & 27 & 74 & TP316H BM \\
3 & & 285 & 561 & 27 & 74 & TP316H BM \\
4 & & 289 & 610 & 25 & 52 & Ni WM \\
5 & $\mathrm{QT} \mathrm{PWHT}+620$ & 304 & 636 & 21 & 51 & Ni WM \\
6 & ${ }^{\circ} \mathrm{C} / 500 \mathrm{~h}$ & 292 & 562 & 14 & 25 & Ni WM/TP316H interface \\
7 & & 287 & 517 & 8 & 14 & T92/Ni WM interface \\
8 & $\mathrm{QT} \mathrm{PWHT}+620$ & 274 & 602 & 25 & 61 & TP316H BM \\
9 & ${ }^{\circ} \mathrm{C} / 2500 \mathrm{~h}$ & 290 & 634 & 22 & 37 & Ni WM/TP316H interface \\
\hline
\end{tabular}

According to the obtained results it can be stated that the tensile deformation and failure behavior of investigated dissimilar weldments clearly exhibited competitive manifestations between the austenitic TP316H region and Ni-based weld metal. In addition, all the fracture locations showed significant hardness peaks due to the locally most intensive, necking-related strain hardening effects occurred during the tensile tests (Figure 10). Moreover, these increased strain hardening effects were often observed not only at the final fracture location (in either TP316 $\mathrm{H}$ or Ni WM region) but also at the location of concurrent necking area (i.e., complementarily in either Ni WM or TP316H region). Figure 11 shows photo-macrographs of selected longitudinal sections of broken tensile specimens' counterparts indicating three different tensile failure locations for the investigated dissimilar weldments in their individual material states.
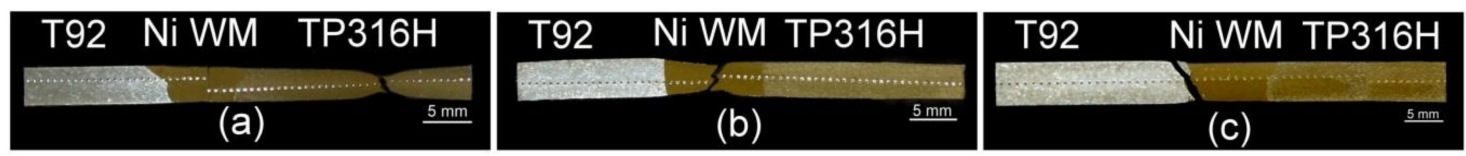

Figure 11. Photo-macrographs of broken tensile specimens' counterparts showing different failure locations after room-temperature tensile tests of T92/TP316H weldments in their individual material states: “QT PWHT” (a); “QT PWHT + $620^{\circ} \mathrm{C} / 500 \mathrm{~h}$ ” (b); “QT PWHT + $620^{\circ} \mathrm{C} / 2500$ h” (c).

At a macroscopic scale, three different failure locations of the investigated dissimilar weldments can be distinguished, namely the failure in BM of TP316 H austenitic steel (Figure 11a), the failure in central part of Ni WM Thermanit Nicro 82 (Figure 11b), and finally the interfacial failure at T92 BM/Ni 
WM interface (Figure 11c). The detailed discussion on the fracture behavior of the studied weldments in relation to their microstructure will be provided in the following section.

\subsection{Ageing Effects on Fracture Behavior in Relation to Microstructure}

As already indicated in Table 2 and Figures 9-11, the room-temperature tensile deformation and failure behavior exhibited competitive manifestations between the austenitic TP316H steel and Thermanit Nicro $82 \mathrm{Ni}$ WM regions. This observation seems to be reasonable because of generally known higher deformability of austenitic alloys compared to the ferritic (also tempered martensitic) ones. In general, the higher deformation ability of austenitic alloys at room temperature than that of the ferritic ones can be related to the existence of close packed crystallographic planes and thus higher number of active slip systems in austenitic alloys with face-centered cubic (f.c.c.) crystal structure compared to ferritic alloys with base-centered cubic (b.c.c.) crystal structure without the close packed planes [29,30]. As already discussed in previous section (Figure 10), the hardness profile of undeformed c-w sample of studied T92/TP316 welded joint before the tensile test, clearly showed lower hardness values for both the austenitic weld portions (i.e., Ni WM and TP316H) compared to T92 tempered martensitic part. However, the applied tensile loading during the tensile tests resulted in intensive strain hardening effects in both the austenitic weld regions. Thus, the preferential deformation of the austenitic weld regions (TP316H, Ni WM) during tensile straining at room temperature gave rise to their higher propensity for local plasticity exhaustion and final failure occurrence. In order to analyze mutual correlation of the weld failure location (Table 2) and the results of tensile tests (Figures 8 and 9), microstructural features just beneath fracture path and fracture surface characteristics for three different failure locations are documented in Figures 12-14. In initial QT PWHT state with a final failure location in $\mathrm{TP} 316 \mathrm{H}$ base material, the appearance of a fracture path indicates the mixed intergranular/transgranular fracture mechanism (see Figure 12a). The austenitic grains of TP316H material beneath fracture location are significantly deformed as a result of intensive necking-related local tensile deformation. A corresponding SEM-fractograph in Figure 12b shows typical dimple tearing areas and pronounced tear ridges observed on the fracture surface within the austenitic TP316H BM region.

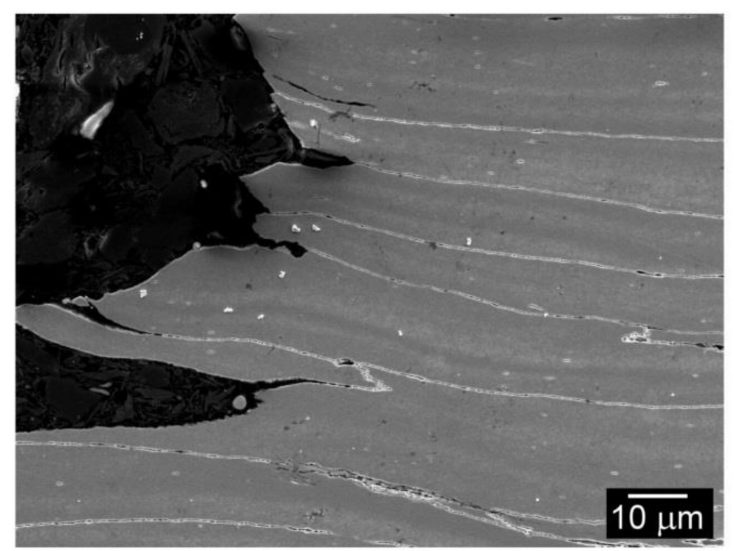

(a)

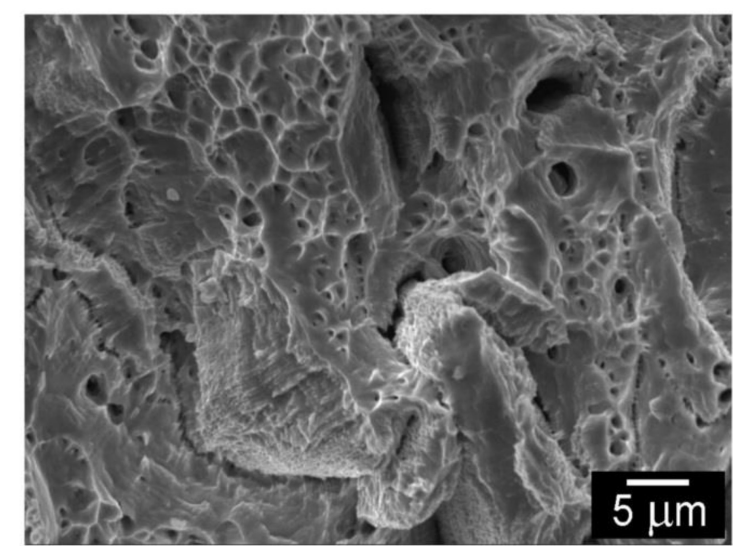

(b)

Figure 12. Fracture analysis of the failure in TP316H steel region after room-temperature tensile test of T92/TP316H dissimilar weldment in "QT PWHT" condition: Fracture path and microstructure beneath the failure (a); Fracture surface with tear ridges and dimple areas (b).

Figure 13a shows a typical microstructure beneath fracture occurred in central region of Ni WM of tensile tested weldment after its isothermal ageing at $620{ }^{\circ} \mathrm{C}$ for $500 \mathrm{~h}$. It preserves its original features already characterized in Section 3.1 (Figure 6); i.e., it exhibits coarse-grained blocky primary $\mathrm{Ti}-\mathrm{Nb}$ or Ti-Nb-B carbo-nitrides and secondary $\mathrm{NbC}$ and $\mathrm{Cr}_{23} \mathrm{C}_{6}$ carbides on migrated high-angle grain 
boundaries. The observed fracture path in Figure 13a and corresponding SEM-fractograph in Figure 13b indicate mixed intergranular/transgranular characteristics of the fracture. Clear decohesion features can be observed at particle/matrix interfaces on grain boundaries of Ni WM (Figure 13a) that represent one example of the mechanism of the documented plasticity degradation (Figures 8 and 9). The major fracture micro-mechanism refers to the microvoid coalescence resulting in the dimpled morphology of the fracture surface (Figure 13b). However, in comparison with the fracture in TP316H region with significantly pulled-out dimples (Figure $12 b$ ), the dimpled fracture in the central region of Ni WM (Figure 13b) contains a higher amount of smaller shallow dimples indicating the material plasticity deterioration. The detailed SEM-micrograph in Figure 13c clearly shows two typical mechanisms of the plasticity deterioration, namely the cracking of the secondary phase particles and the intergranular decohesion related to the cracking at the intergranular particle/matrix interfaces.

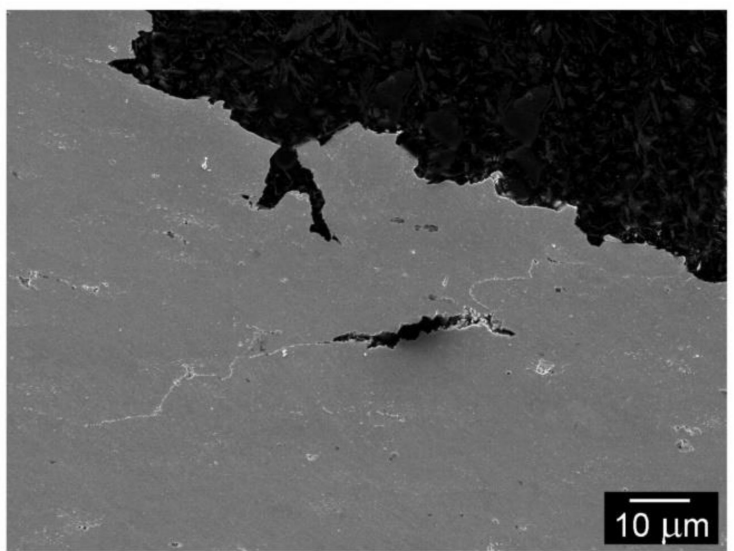

(a)

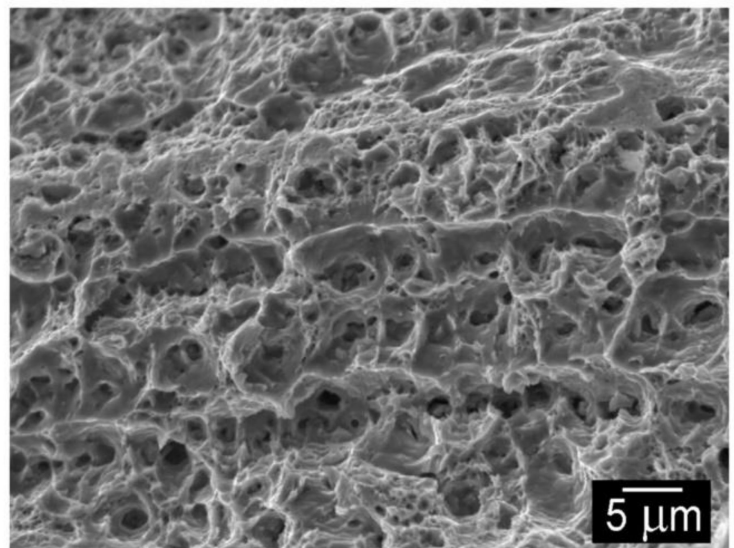

(b)

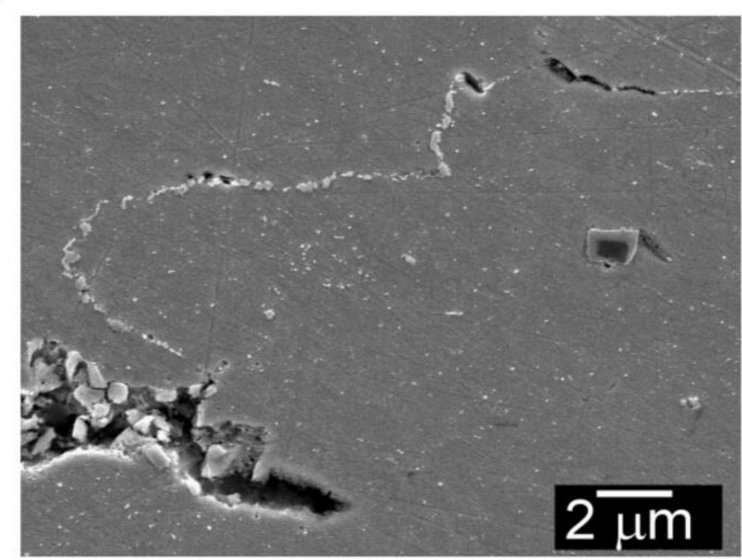

(c)

Figure 13. Fracture analysis of the failure in Ni WM central region after room-temperature tensile test of T92/TP316H dissimilar weldment in "QT PWHT $+620^{\circ} \mathrm{C} / 500 \mathrm{~h}$ " condition: Fracture path and microstructure beneath the failure (a); Fracture surface showing dimple areas (b); Detailed view of the mechanisms of plasticity deterioration (c).

The sub-fracture microstructure of tensile tested weldment thermally exposed at $620^{\circ} \mathrm{C}$ for $2500 \mathrm{~h}$ is visualized in Figure 14a,b. The detailed observation revealed that the macroscopically classified interfacial failure (Figure 11c) did not occur directly at the T92 BM/Ni WM interface but the fracture ran partly through T92 BM and largely through precipitation-depleted zone (PDZ) of Ni WM located at a distance of about $5-8 \mu \mathrm{m}$ from the fusion boundary (see Figure 14a,b). The occurrence of PDZ in Ni WM can presumably be related to specific welding metallurgy phenomena such as weld metal dilution, the presence of unmixed or partially melted zone, and/or type II boundaries formation $[4,13,31-35]$. 
It should be stated that all of these phenomena have been indeed noticed at several locations of Ni WM/T92 BM dissimilar weld interface of the welds investigated. However, the detailed study of Ni WM and specifically its interfacial microstructures including the characterization of densely distributed fine precipitates next to the PDZ will the subject of our separate investigation. It is worth noting that the typical mechanisms of the plasticity deterioration, namely the cracking of secondary phase particles and decohesion at particle/matrix interfaces were also clearly observed in T92 region of Figure 14b. However, since the majority of the fracture occurred in PDZ of Ni WM, a corresponding SEM-fractograph is visualized in Figure 14c. It clearly shows visible signs of thermal embrittlement represented by shallow dimples combined with indications of fine quasi-cleavage areas. This observation correlates well with the lowest plasticity determined by the tensile tests for the weld material state with the highest duration of thermal exposure (Figures 8 and 9). Complementarily to the fracture path analysis (Figure 14a,b) and fracture surface analysis (Figure 14c), an EDX analysis (Figure 14d) from the sub-fracture area confirmed that substantial portion of the fracture was located within Ni WM dilution area.

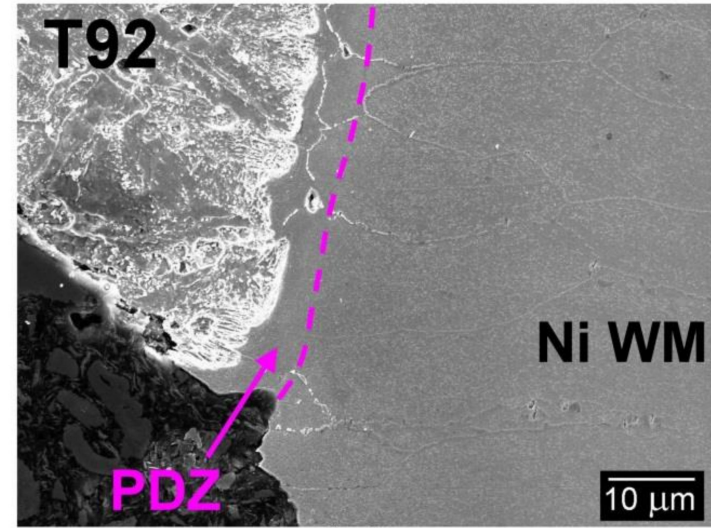

(a)

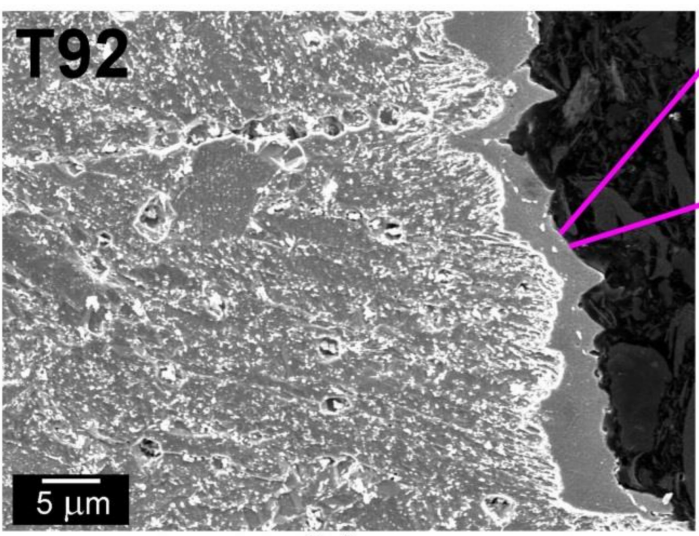

(b)

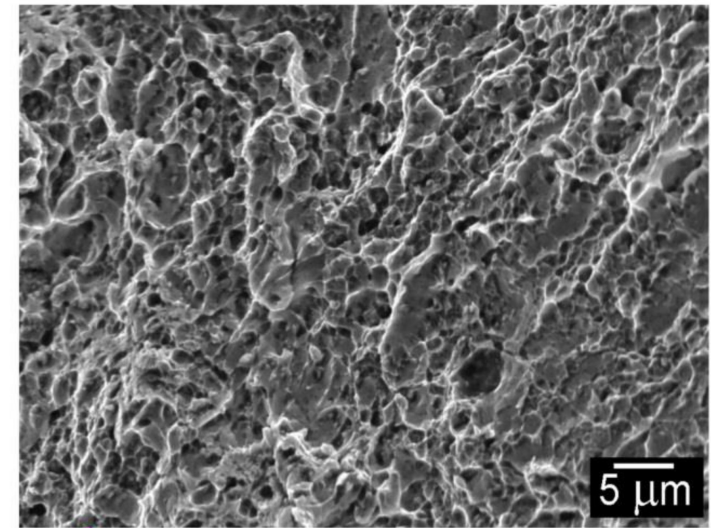

(c)

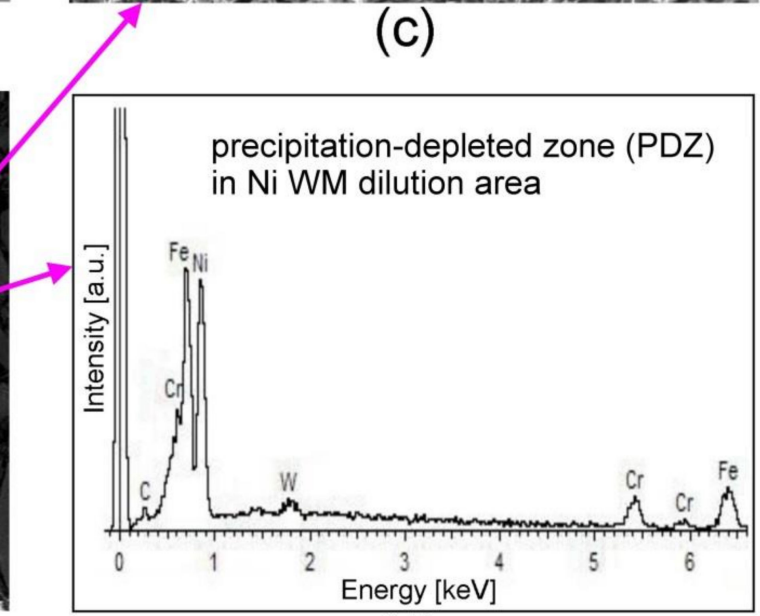

(d)

Figure 14. Fracture analysis of the failure occurred in vicinity of $\mathrm{T} 92 \mathrm{BM} / \mathrm{Ni}$ WM interface after room-temperature tensile test of T92/TP316H dissimilar weldment in “QT PWHT $+620^{\circ} \mathrm{C} / 2500 \mathrm{~h}$ " condition: Fracture path and microstructure beneath the failure $(\mathbf{a}, \mathbf{b})$; Fracture surface showing dimple and intensive shear areas (c); Typical EDX spectrum of Ni WM dilution area at the fracture location (d).

The detailed SEM microstructure beneath the fracture path in Figure 15 clearly shows all indicated mechanisms of plastic properties degradation after the longest studied thermal exposure $\left(620^{\circ} \mathrm{C} / 2500 \mathrm{~h}\right)$ of the investigated dissimilar weldment. When considering the room-temperature tensile deformation behavior of the studied dissimilar weldments, it is reasonable to expect the failure occurrence in the region with the lowest tensile strength for a given weld material state. Furthermore, 
it has been clearly evidenced (Figure 10) that the effects of strain hardening and plasticity exhaustion play an important role in the final failure occurrence. The observed changes of failure locations among individual weld material states (Table 2) can be directly related to gradual evolution of thermal embrittlement effects in critical weld regions during performed ageing exposure (Figures 12-15).

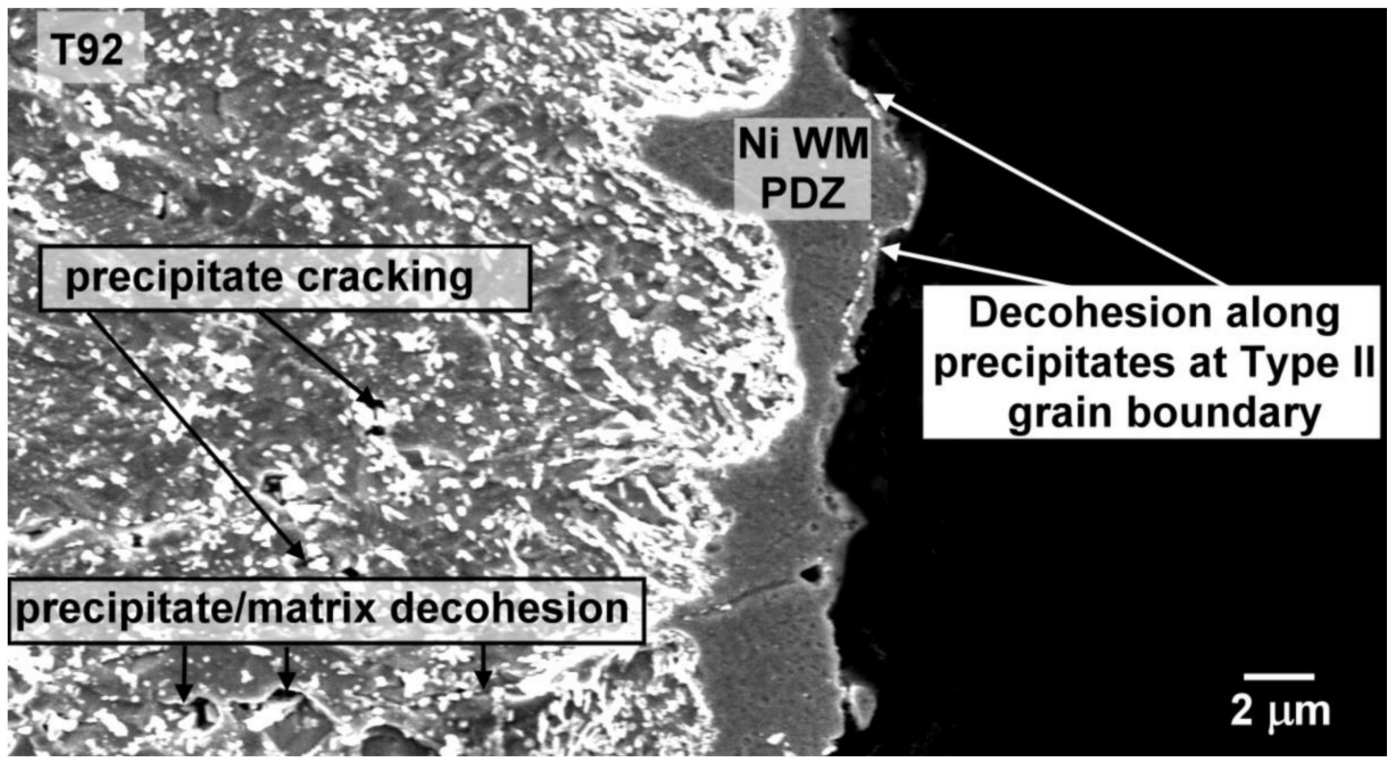

Figure 15. The mechanisms of plasticity degradation of thermally exposed $\left(620{ }^{\circ} \mathrm{C} / 2500 \mathrm{~h}\right)$ T92/TP316H nickel-based transition weldment subjected to tensile testing at room temperature.

The obtained results clearly indicate that the Ni WM and especially its interfacial region with T92 BM belong to the weld most critical regions with respect to failure occurrence after long-term thermal exposure.

Our future research will be focused on a continuation of the present investigation towards longer ageing experiments, creep tests, and hydrogen embrittlement studies in relation with the welds microstructure degradation characterization, aiming at a reliable prediction of their life-time performance in high-temperature steam circuits of highly-efficient environmentally friendly power plants.

\section{Summary and Conclusions}

Unconventionally post-weld heat treated (specifically: quenched and tempered) T92/TP316H martensitic/austenitic weldments with Ni-based weld metal (Thermanit Nicro 82) were subjected to long-term isothermal ageing at $620^{\circ} \mathrm{C}$ for up to $2500 \mathrm{~h}$ in order to investigate the effects of thermal embrittlement evolution on room-temperature tensile properties and fracture behavior in relation with microstructure. From the obtained results the following conclusions could be drawn:

- In the initial material state i.e., in QT PWHT condition, microstructural observation and cross-weld hardness measurement of the studied weldment revealed that the use of unconventional two-step PWHT resulted in clear microstructural homogenization (i.e., no HAZ microstructural gradients) and hardness values equalization within the both weld base materials (T92 and TP316H).

- Subsequent ageing effects at $620^{\circ} \mathrm{C}$ of the studied weldments resulted in gradual changes in their individual microstructures represented mainly by additional precipitation and coarsening of secondary phase precipitates. These microstructural changes resulted in significant detrimental effects on the welds plasticity (EL, RA values), whereas their effects on the welds strength (Re, Rm values) were rather small.

- The effects of thermal exposure resulted also in several changes of failure locations within the studied weldments. In the initial QT PWHT condition, the failure occurred always in TP316H steel 
base material. After the ageing at $620^{\circ} \mathrm{C}$ for $500 \mathrm{~h}$, the weld failure location was in major cases in central part of Ni WM. The weld failures after the longest thermal exposure $\left(620^{\circ} \mathrm{C} / 2500 \mathrm{~h}\right)$ were different for each individual tensile test. The most brittle failure was the failure in the vicinity of T92/Ni WM interface.

- By analyzing the fracture path and microstructural features beneath the fracture surfaces, the clearly observed mechanisms of the welds plasticity deterioration after thermal exposure are related to the cracking of coarse secondary phase particles and interfacial decohesion at precipitate/matrix interfaces during tensile straining. After the longest applied thermal exposure $\left(620^{\circ} \mathrm{C} / 2500 \mathrm{~h}\right)$, interfacial decohesion occurred in Ni WM dilution area along the precipitates at Type II grain boundary.

- Fractographic analyses of fracture surfaces of broken tensile samples also revealed clear evolution of thermal embrittlement processes depending on the thermal exposure duration. In the initial QT PWHT material state, the fracture surface related to the failure in TP316H BM showed pulled-out dimples and pronounced tear ridges. Thermal exposure of the weldment at $620^{\circ} \mathrm{C}$ for $500 \mathrm{~h}$ resulted in failure located in Ni WM. It also showed dimple morphology but without pronounced tear ridges. The most thermally embrittled material state of the weldment aged at $620^{\circ} \mathrm{C}$ for $2500 \mathrm{~h}$ exhibited small shallow dimples combined with fine quasi-cleavage areas on the fracture surface.

- The most of fracture locations of the studied weldments in their individual material states exhibited significant hardness peaks due to the intensive, necking-related strain hardening effects that occurred during the room-temperature tensile tests.

- The tensile deformation and fracture processes of the weldments in their individual material states exhibited competitive behavior between the austenitic TP316H region and Ni-based weld metal. The observed changes in failure locations for individual material states of the weldment can be directly related to specific thermal embrittlement evolution in critical weld regions during performed isothermal ageing. The obtained results indicate that the Ni WM and T92/Ni WM interfacial region represent the most critical zones of the investigated weldment with respect to the failure occurrence after long-term thermal exposure.

Author Contributions: Conceptualization, L.Č. and L.F.; Methodology, L.Č., P.Š. and M.D.; Validation, L.Č. and M.D.; Formal Analysis, L.Č., L.F. and M.D.; Investigation, L.Č., L.F., P.Š., M.V. and M.D.; Resources, M.D.; Data Curation, L.Č., L.F. and M.D.; Writing-Original Draft Preparation, L.F.; Writing-Review \& Editing, L.F.; Visualization, L.Č. and L.F.; Supervision, L.F. and P.Š.; Project Administration, P.Š. and L.F.; Funding Acquisition, P.Š.

Funding: This research was funded by “Vedecká Grantová Agentúra MŠVVaŠ SR a SAV” (project “VEGA 2/0151/16”).

Acknowledgments: This work was supported by "Vedecká Grantová Agentúra MŠVVaŠ SR a SAV" under the project "VEGA 2/0151/16" and partly by "Agentúra na Podporu Výskumu a Vývoja" under the contract "APVV-16-0194". The work was also realized within the frame of the project "ITMS 26220220186".

Conflicts of Interest: The authors declare no conflict of interest.

\section{References}

1. Parker, J.D.; Stratford, G.C. The high-temperature performance of nickel-based transition joints II. Fracture behaviour. Mater. Sci. Eng. A 2001, 299, 174-184. [CrossRef]

2. Anand, R.; Sudha, C.; Karthikeyan, T.; Terrance, A.L.E.; Saroja, S.; Vijayalakshmi, M. Effectiveness of Ni-based diffusion barriers in preventing hard zone formation in ferritic steel joints. J. Mater. Sci. 2009, 44, $257-265$. [CrossRef]

3. Kim, R.; Kwak, S.-C.; Choi, I.-S.; Lee, Y.-K.; Suh, J.-Y.; Fleury, E.; Jung, W.-S.; Son, T.-H. High-temperature tensile and creep deformation of cross-weld specimens of weld joint between T92 martensitic and Super304H austenitic steels. Mater. Charact. 2014, 97, 161-168. [CrossRef]

4. Mittal, R.; Sidhu, B.S. Microstructures and mechanical properties of dissimilar T91/347H steel weldments. J. Mater. Process. Technol. 2015, 220, 76-86. [CrossRef] 
5. Silwal, B.; Li, L.; Deceuster, A.; Griffiths, B. Effect of postweld heat treatment on the toughness of heat-affected zone for Grade 91 steel. Weld. J. 2013, 92, 80-87.

6. Sklenička, V.; Kuchařová, K.; Svobodová, M.; Kvapilová, M.; Král, P.; Horváth, L. Creep properties in similar weld joint of a thick-walled P92 steel pipe. Mater. Charact. 2016, 119, 1-12. [CrossRef]

7. Pandey, C.; Mahapatra, M.M.; Kumar, P.; Saini, N. Dissimilar joining of CSEF steels using autogenous tungsten-inert gas welding and gas tungsten arc welding and their effect on $\delta$-ferrite evolution and mechanical properties. J. Manuf. Process. 2018, 31, 247-259. [CrossRef]

8. Zhang, J.; Du, B.Sh.; Li, X.M.; Qin, G.L.; Zou, Y. Microstructure evolution of P92 steel weld metal after service for 8000 h. Kovove Mater. 2017, 55, 115-121. [CrossRef]

9. Wu, Q.; Lu, F.; Cui, H.; Ding, Y.; Liu, X.; Gao, Y. Microstructure characteristics and temperature-dependent high cycle fatigue behavior of advanced $9 \% \mathrm{Cr} / \mathrm{CrMoV}$ dissimilarly welded joint. Mater. Sci. Eng. A 2014, 615, 98-106. [CrossRef]

10. Cao, J.; Gong, Y.; Zhu, K.; Yang, Z-G.; Luo, X-M.; Gu, F-M. Microstructure and mechanical properties of dissimilar materials joints between T92 martensitic and S304H austenitic steels. Mater. Des. 2011, 32, 2763-2770. [CrossRef]

11. Chen, G.; Song, Y.; Wang, J.; Liu, J.; Yu, X.; Hua, J.; Bai, X.; Zhang, T.; Zhang, J.; Tang, W. High-temperature short-term tensile test and creep rupture strength prediction of the T92/TP347H dissimilar steel weld joints. Eng. Fail. Anal. 2012, 26, 220-229. [CrossRef]

12. Wang, W.; Wang, X.; Zhong, W.; Hu, L.; Hu, P. Failure analysis of dissimilar steel welded joints in a 3033t/h USC boiler. Procedia Mater. Sci. 2014, 3, 1706-1710. [CrossRef]

13. Karthick, K.; Malarvizhi, S.; Balasubramanian, V.; Krishnan, S.A.; Sasikala, G.; Albert, S.K. Tensile and impact toughness properties of various regions of dissimilar joints of nuclear grade steels. Nucl. Eng. Technol. 2018, 50, 116-125. [CrossRef]

14. Rathod, D.W.; Pandey, S.; Singh, P.K.; Prasad, R. Experimental analysis of dissimilar metal weld joint: Ferritic to austenitic stainless steel. Mater. Sci. Eng. A 2015, 639, 259-268. [CrossRef]

15. Wang, H.T.; Wang, G.Z.; Xuan, F.Z.; Tu, S.T. Fracture mechanism of a dissimilar metal welded joint in nuclear power plant. Eng. Fail. Anal. 2013, 28, 134-148. [CrossRef]

16. Li, Y.; Wang, J.; Han, E.-H.; Yang, C. Structural, mechanical and corrosion studies of Cr-rich inclusions in 152 cladding of dissimilar metal weld joint. J. Nucl. Mater. 2018, 498, 9-19. [CrossRef]

17. Cao, J.; Gong, Y.; Yang, Z.-G. Microstructural analysis on creep properties of dissimilar materials joints between T92 martensitic and HR3C austenitic steels. Mater. Sci. Eng. A 2011, 528, 6103-6111. [CrossRef]

18. Falat, L.; Výrostková, A.; Svoboda, M.; Milkovič, O. The influence of PWHT regime on microstructure and creep rupture behaviour of dissimilar T92/TP316H ferritic/austenitic welded joints with Ni-based filler metal. Kovove Mater. 2011, 49, 417-426. [CrossRef]

19. Falat, L.; Čiripová, L.; Kepič, J.; Buršík, J.; Podstranská, I. Correlation between microstructure and creep performance of martensitic/austenitic transition weldment in dependence of its post-weld heat treatment. Eng. Fail. Anal. 2014, 40, 141-152. [CrossRef]

20. Falat, L.; Kepič, J.; Čiripová, L.; Ševc, P.; Dlouhý, I. The effects of postweld heat treatment and isothermal aging on T92 steel heat-affected zone mechanical properties of T92/TP316H dissimilar weldments. J. Mater. Res. 2016, 31, 1532-1543. [CrossRef]

21. Nhung, L.T.; Khanh, P.M.; Hai, L.M.; Nam, N.D. The relationship between continuous cooling rate and microstructure in the heat affected zone (HAZ) of the dissimilar weld between carbon steel and austenitic stainless steel. Acta Metall. Slovaca 2017, 23, 363-370. [CrossRef]

22. Lee, S.-H.; Na, H-S.; Lee, K-W.; Lee, J-Y.; Kang, C.Y. Effect of austenite-to-ferrite phase transformation at grain boundaries on PWHT cracking susceptibility in CGHAZ of T23 steel. Metals 2018, 8, 416. [CrossRef]

23. Kral, P.; Dvorak, J.; Sklenicka, V.; Masuda, T.; Horita, Z.; Kucharova, K.; Kvapilova, M.; Svobodova, M. The effect of ultrafine-grained microstructure on creep behaviour of 9\% Cr steel. Materials 2018, 11, 787. [CrossRef] [PubMed]

24. Zhao, L.; Jing, H.; Xu, L.; Han, Y.; Xiu, J. Experimental study on creep damage evolution process of Type IV cracking in 9Cr-0.5Mo-1.8W-VNb steel welded joint. Eng. Fail. Anal. 2012, 19, 22-31. [CrossRef]

25. Barbadikar, D.R.; Deshmukh, G.S.; Maddi, L.; Laha, K.; Parameswaran, P.; Ballal, A.R.; Peshwe, D.R.; Paretkar, R.K.; Nandagopal, M.; Mathew, M.D. Effect of normalizing and tempering temperatures on 
microstructure and mechanical properties of P92 steel. Int. J. Press. Vessels Pip. 2015, 132-133, 97-105. [CrossRef]

26. Blach, J.; Falat, L.; Ševc, P. Fracture characteristics of thermally exposed 9Cr-1Mo steel after tensile and impact testing at room temperature. Eng. Fail. Anal. 2009, 16, 1397-1403. [CrossRef]

27. Blach, J.; Falat, L. The influence of thermal exposure and hydrogen charging on the notch tensile properties and fracture behaviour of dissimilar T91/TP316H weldments. High Temp. Mater. Process. 2014, 33, 329-337. [CrossRef]

28. Falat, L.; Čiripová, L.; Homolová, V.; Kroupa, A. The influence of isothermal ageing and subsequent hydrogen charging at room temperature on local mechanical properties and fracture characteristics of martensitic-bainitic weldments for power engineering. J. Min. Metall. Sect. B-Metall. 2017, 53, 373-382. [CrossRef]

29. Cottrell, A.H. Theory of dislocations. Prog. Met. Phys. 1953, 4, 205-264. [CrossRef]

30. Hirth, J.P. Dislocations. In Physical Metallurgy, 4th ed.; Cahn, R.W., Haasen, P., Eds.; Elsevier Science: Amsterdam, The Netherlands, 1996; Volume III, ISBN 978-0-444-89875-3.

31. Shin, K.-Y.; Lee, J.-W.; Han, J.-M.; Lee, K.-W.; Kong, B.-O.; Hong, H.-U. Transition of creep damage region in dissimilar welds between Inconel $740 \mathrm{H}$ Ni-based superalloy and $\mathrm{P} 92$ ferritic/martensitic steel. Mater. Charact. 2018, 139, 144-152. [CrossRef]

32. Pavan, A.H.V.; Vikrant, K.S.N.; Ravibharath, R.; Singh, K. Development and evaluation of SUS304H-IN 617 welds for advanced ultrasupercritical boiler applications. Mater. Sci. Eng. A 2015, 642, 32-41. [CrossRef]

33. Choi, K.J.; Kim, T.; Yoo, S.C.; Kim, S.; Lee, J.H.; Kim, J.H. Fusion boundary precipitation in thermally aged dissimilar metal welds studied by atom probe tomography and nanoindentation. J. Nucl. Mater. 2016, 471, 8-16. [CrossRef]

34. Dong, L.; Peng, Q.; Han, E-H.; Ke, W.; Wang, L. Microstructure and intergranular stress corrosion crackingsusceptibility of a SA508-52M-316L dissimilar metal weld joint in primary water. J. Mater. Sci. Technol. 2018, 34, 1281-1292. [CrossRef]

35. Yoo, S.C.; Choi, K.J.; Bahn, C.B.; Kim, S.H.; Kim, J.Y.; Kim, J.H. Effects of thermal aging on the microstructure of Type-II boundaries in dissimilar metal weld joints. J. Nucl. Mater. 2015, 459, 5-12. [CrossRef] 